\title{
Amrit Sanskar (Baptism) and the Challenges in the Sikh Community in Malaysia
}

\author{
Aman Daima Md. Zain \\ Department of Theology and Philosophy \\ The National University of Malaysia \\ Dr. Jaffary Awang \\ Associate Prof. Department of Theology and Philosophy \\ The National University of Malaysia
}

\section{Doi:10.5901/ajis.2013.v2n8p50}

\section{Abstract}

In the Malaysian context, the Sikh community is still categorised as the minority ethnic as compared to other ethnic groups. Their arrival in Malaysia (previously named Malaya) mid-19th century had formed a Sikh community with their own identity. This identity is known as panch kekaar or 5K's comprising of five symbols which are Kesh (long hair), Kara (metal bracelet), Kirpan (small sword), Kachera (shorts) and Kangha (comb). All these five symbols are formed through a baptist ceremony called amrit sanskar during the leadership fo the last Sikh master named Guru Gobind Singh (1675-1708). Those who have undergone this amrit sanskar are accepted to become the solidarity members of Khalsa; those who are regarded as pure in the Sikh religion. However, in the Sikh community in Malaysia, this ceremony of amrit sanskar that seeks to form such an identity does have its own challenges and issues. Taken from several selected writings, there are three challenges that need to be resolved by the Sikh people in order to form their own identity. The challenges include the weakness of the Granthi Sahib, the weakness of the gurdwara management committee (JPG) and the clash of the local cultures. Among the objectives of this paper work is to share some information on the religion of the minority in Malaysia. This paper also concludes that the challenges that prevail in the formation of the Sikh identity will continue through amrit sanskar especially among the younger generation as long as the three issues remain unresolved

Keywords : amrit sanskar, Sikh, Malaysia, identity

\section{Introduction}

In the context of the plural community in Malaysia, the Sikh community is still categorized as a minority. They have different history, religion and language from the Tamil community although both originate from the Indian continent (Azharudin, 2002 :1). As of today, the Sikh community in Malaysia has contributed in almost all of the professional fields either in the fields of medicine, services, education and others. Although with the population of 80,000 people, they are able to compete with other groups in various fields in which they embark (Darshan S. Gill, $2009: 57$ ).

Just as every ethnic groups has their own characterictics that epitomize their identity, same goes with the Sikh. The Sikh identity is formed through the determination of the Sikh religion and it is collective by nature. This identity is very much linked with the definition on a Sikh follower. Shiromani Gurdwara Parbandhak Committee (SGPC), a body that is responsible in administering the affairs of the Sikh religion centered in Amritsar, Punjab India has defined a Sikh follower as follows:

A Sikh is any person whose faith consists of belief in one God, the ten Gurus, the Guru Granth Sahib and other scriptures of the Sikh religion. Additionally, he or she must believe in the necessity and importance of amrit (the Sikh Comformational ceremmony)

Based on this definition, it shows that the true Sikh will be menifested through amrit sanskar ceremony (Sarjit S. Gill, 2008 :30-31). Rooted from this, there is the emerging Khalsa group, who specifically portrays the identity of the Sikh religious followers. The adopt the 5K namely Kesh (long hair), Kara (metal bracelet), Kirpan (small sword), Kachera (shorts) and Kangha (comb) as their identity (Aman Daima, 2001: 84). The elaboration of these five symbols is as follows: 


\subsection{Kesh}

Kes means hair and the hairs found on the human body. Sikh followers believe that Kes is granted by God, and it marks the highest achievement and position of Guru Gobind Singh (1675-1708) and the final Sikh Guru (Ganga S. Gyani, 1962 : 2). This explains why the Sikh does not allow its followers, men or women, to cut their hair or shave the hairs on their bodies and that they must be kept clean (Aman Daima, 2001: 57). They also believe that long hair and beard will make it more convenient for them to obey God's orders. It is based upon this belief that all ten Sikh masters have kept their hair and beard long. It is also in their belief system that before they open themselves to the teachings of the Sikh gurus, they must first have some resemblance with the teachers' form and physicality. Long hair and beard is also one of the terms juga merthat must be adhered by the Sikh people in order to become true followers. Thus, those who cut their hair and beard are called 'Patit' which means 'traitor' (Sikh Naujawan Sabha, 1969: 27).

\subsection{Kangha}

Kangha means a wooden comb and must always be placed in the turban. This comb must be respected by the Sikh people as it is closely knitted with Kes. With the presence of the comb, Sikh followers will always look neat and clean all the time. This is why they are encouraged to comb their hair at least twice a day. By doing that, they believe that they will be able to remember that their hearts must also be cleansed so that it will become clean and pure all the time (Agus Salim, 1985 :188). Here, the relationship between Kangha and Kes is complementary between one another as ruffled, uncombed Kes will make the hair untidy and knotted. It is also obligatory for the Sikh followers to put the Kangha on their heads as a symbol of living in discipline and with rules and regulations (H.S Singha \& Satwant K., 1994: 108).

\subsection{Kara}

Kara means metal bracelet and it is compulsory for Sikh men and women to wear it. This adornment is to show that they are followers who are loyal to the Sikh teachings and they should remember doing good things with their hands like working hard, helping people in difficulty and in need of help (Aman Daima, 2001:64). Philosophically, Kara carries two meanings in the life of the Sikh people. The first is that the circle of the bracelet implies the condition where there is no beginning and there is no ending. This brings us to the concept of universality, that is characteristic of the community's social condition. Those who wear Kara are thought of as individuals who tolerate all creatures, other than believe in human solidarity. The second meaning lies in the metal itself, one that is very useful in human life. Its rough and hard nature, shows that they are not going to succumb and surrender to any form of threat and torture (Sahib Singh, 1967:108 \&109).

\subsection{Kachera}

Kachera points to the shorts worn by the Sikh people down to their knees (Khuswant Singh, 1963:84). They are almost similar to the ones worn by the soldiers and they are cut and sewn specially for the Sikh people. It symbolises nobility and purity in one's married life or which is called in the Sikh religion as Gristi Jiwan (Ganga S. Gyani, 1962:109). Kachera as a main symbol of the Sikh community serves as a clothing for the Indians since some time back, but its form and fashion had changed after being influenced by the changing era. Other than serving as a form of clothing to the Sikh people, Kachera also signifies the soul and mind that are liberated from traditional ways of thinking (H.S Singha \& Satwant K., 1994:109). Symbolically, behind this, a husband or a wife will always be faithful to his or her spouses. It is also a show of brevity and heroism, in defending oneself and religion from enemy (Sikh Naujawan Sabha, 1969:28).

\subsection{Kirpan}

Kirpan is double-edged sword and is used by the Sikh people on their belts (Archer, 1971:196). It is a symbol of strength and a precious weapon for Sikh followers. Those who carry this shall be regarded as a loyal follower and have strong faith (Sikh Naujawan Sabha, 1969:28). Kirpan will remind them about why they are brought to this world, which is to preserve justice, help the weak and the incapable (Aman Daima, 2001:60). Every Sikh person carrying Kirpan will see it as a gift from Guru Gobind Singh. It will not only be perceived as a weapon for defence, but sserves as an external symbol for the soul and spirit who are never lost and disappointed (Ranbir Singh, 1965:265). 
All these five symbols are inextriably linked with the psychological elements experienced by Guru Gobind Singh when he was nine years old, after hearing about his father, Guru Tegh Bahadur being beheaded by the Moghul Ruler in Chandni Chauk, Delhi. Thus, the founding of the Khalsa group with the five symbols has changed the status of the Sikh people from the image of a sparrow to a hawk. In other words, the emergence of Khalsa is yielded by Guru Gobind Singh's resentment and revenge on the Moghul government. Therefore, he had instructed his followers to weal all five symbols as the uniform identity of the Khalsa (Sardar Singh Rataul, 1964:27).

Now, the time has changed. The concept of Khalsa is no longer based on revenge to the Moghul rulers, but more to the formation of the Sikh identity which denotes those who are loyal to the teachings of Sikh which is suitable to the passing of the era. This identity is prioritised in their daily lives. Thus, in a Skh marriage, if one of the spouses is not from the Sikh descent, then he or she must first become a member of the Khalsa by undergoing the amrit sanskar ceremony (Sarjit S. Gill, 2001:19). Therefore, the wearing of these symbols has placed the Khalsa at high position in the Sikh religion and this has automatically become their identity.

Nonetheless, the identity formation through amrit sanskar in the context of the Sikh community in Malaysia today does have some shortcomings. The first issue lies in the weakness of the granthi sahib in givign religious messages to the Sikh community. The second issue is the weakness of the manegement committee of the gurdwara (JPG) in handling the gurdwara and its operations. The third issue lies in the clash of the local and the western cultures, also the influence they have on the formation of identity of the Sikhs in Malaysia.

\section{The weakness of the Granthi Sahib}

To undergo amrit sanskar, first of all every member of the the Sikh community should have an understanding on the teachings of the religion. Without an understanding on the religious teachings, they will not be prepared to undergo amrit sanskar. This is due to the fact that amrit sanskar will be held when there is a request from the Sikh community. At this point, Granthi sahib is one held accountable in delivering religious messages to the Sikh community in religious centers called the gurdwara. However, reality has it that the granthi sahib shows weakness in delivering religious messages as contained in the book of Guru Granth Sahib to the Sikh masses. Nonetheless, according to Charanjit Kaur (2002) and Sarjit S. Gill (2005), the role and the duties of the granthi sahib have become more and more of a challenge following several reasons. The first is the intervention of the Gurdwara Management Committee (JPG) in deciding on the roles of the granthi sahib where some have been appointed as normal employees and guards of the gurdwara, and not as religious experts. They are often made the target, should there be any matters arising at the gurdwara. This has led to their restricted roles as they only carry out the duties as instructed by the JPG only.

The second reason is that in Malaysia, most gurdwaras have to depend on the granthi sahib imported from Punjab, India. In Malaysia, they are only paid the salary of RM800 to RM1200 only without special provisions, such as allowance, annual leave and medical facilities. Thus, they are forced to make Malaysia a transit to other places which happen to pay them more. They only come to earn their living and fill in the vacancy. The majority of the granthi sahib from India do not even have the suitable 'package' with today's challenges, in terms of their intellect and understanding in the field of comparative religion. They also do not give religious talk in series and only read messages from the book of Sri Guru Granth Sahib Ji without so much caring if the Sikh community understands it or not.

The third reason is the fact that the granthi sahib is not able to interact in English or Bahasa Malaysia but is much comfortable interacting in the Punjabi language, whereas the Sikh community especially the younger ones are still lagging behind in mastering the Pujabi language. Thus, as Sarjit S. Gill (2008:41) puts it, the dependency on the granthi sahib from India will continue to happen and will in fact, leave a long-term effect to the Sikh community living in Malaysia. In turn, the younger generation would not be interested in getting involved in this field, due to the salary and pressure exerted by the JPG.

\section{The weakness of the Gurdwara Management Commitee (JPG)}

The members of the JPG are selected by the votes obtained by the Sikh community through the electoral system held at the gurdwara premise. Those who are chosen as the members of the JPG ahve a great role to play, in executing the programs beneficial to the Sikh community either in the form of the organization of the religious activities, religious classes, financial management and so on. To render the activities a success, the cooperation between the members of the JPG and the Sikh community is pivotal. According to Sarjit S. Gill (2005), JPG itself contains three kinds of weaknesses. The first rests in the fact that the JPG does not give room to the Sikh community to speak up and give 
comments, while they have the rights to do so, let alone declining and refusing any decisions that have been made by the JPG. This lack of space for the Sikh community to voice their concern, has caused the JPG to have full power and authority in determining the running of the gurdwara. Thus, annual meeting held has often become 'heated' with arising issues, that subsequently do not get the attention of the JPG frontmen throughout their administration.

Next, most of the JPG members are monopolised by the elder generation and that only few youths tend to get selected. This provides the right condition to the fact that new ideas from the younger generations have not been able to brought forward to the JPG, and this is added by the 'trend' whereby the older generation is inclined to have a dispute among themselves and fail to become the role model to the younger counterparts, especially in terms of the religious practice. This stems from the younger generation's restrictions in becoming the members of the gurdwara to enable them to be qualified as members of the JPG. Although the gurdwara membership criteria are open to individuals aged 18 years and above, without accounting for the socio-economic status and gender, university and college students are not allowed to become members, except if they have obtained the permission from their learning institutions.

The lack of cooperation given by the members of the JPG appointed stands out as the third reason. This cooperative attitude is important because the individuals selected in the JPG are not given any compensation or rewards, and as a matter of fact they have to be prepared to sacrifice their time and energy voluntarily when their help is needed by the Sikh community. What really happens is that not all members of the JPG are selected based on the spirit of cooperation, but due to other factors such as having wealth, high status in the society and also forming close political relationships with the Malaysian Indian Congress (MIC) which represents the Indians in Malaysia. Those selected begin their agenda by recruiting new members for their own party (Savinder K. Gill \& Nirmala Devi Gopal 2010 :144). According to the study done by Sarjit S. Gill \& Charanjit Kaur (2008 : 250), Gurdwara Sahib, Petaling Jaya in Selangor and Gurdwara Sahib Tatt Khalsa Diwan in Kuala Lumpur are two gurdwaras which have a close relationship with the MIC.

Thus, these issues have left an impact to the Sikh community as they are trying to develop an understanding on the teachings of Sikh religion in the gurdwara and prepare themselves to undergo the process of amrit sanskar.

\section{Clash of Cultures}

The meeting of both the Western and the local cultures not influences the formation of identity of the Sikh community especially its younger people, but also the younger generations of other ethnic groups. In the pluralistic society in Malaysia, the Sikh community is surrounded by the Muslimc community, of which the majority are Malays. The work of Aman Daima (2001) demonstrates not all Sikh people in Kelantan practise 5K the identity of the Sikhs and prepare to accept amrit to become members of the Khalsa group. Among the excuses given especially by the youths is that they are embarrassed to face the Kelantanese, and their culture- this is so since the majority of the Kelantanese are Muslim Malays.

Tis is in line with the study of Sarjit S. Gill (2005) which has concluded that the majority of the Punjabi mixedcommunity in Kota Kinabalu, Sabah are still practising their own traditional culture be it the cultures of the Kadazan, Murut and Cina. Although the mixed-community of Punjab still embraces the Sikh religion, the Punjabiembrace Christianity and Islam. There are even a number of Sikh followers who have become part of Khalsa and wear 5K, but still fail at following the basic teachings of Sikh religion, so much so that they have disobeyed the religious laws and further ruined the identity of the religion.

Their failure at defending the culture of the Punjab and simultaneously maintaining the traditional culture, actually has a lot to do with the weaknesses shown by the JPG and granthi sahib in performing their own duties. This link is evident through JPG's attitude which does not seem to have an interest in empowering the Punjab culture in the gurdwara. The Punjab language classes have not been done, as planned. In effect, they have not been able to understand the Punjab language, although it is this language that has been used by granthi sahib in religious affairs held at the gurdwara. Additionally, there is the problem of the scarcity of Sikh religious books in the Malay version which is in the language that they understand. Consequently, the Punjab descent has become distant with the gurdwara and choose the shorter and simpler way out by leaving Sikhism altogether or return to their original traditional culture.

It is because of this that Khoo Kay Kim (2002) points out that the collision of cultures among the Sikh people for about 40 years' back has raised a great concern among the elderly. They are not only exposed to the western culture which carries varying lifestyles, values and life philosophies, but also to the the cultures of other groups in Malaysia, causing the gap to widen in the fundamental teaching of Sikhism. With this in mind, the meeting of both cultures, the Sikh culture and those of the pluralistic society in Malaysia has auomatically influenced the Sikh community to stand by their own identity and which pushes them to become part of Khalsa through the amrit sanskar ceremony. 


\section{Closing}

Based on these three challenges, the Sikh community in Malaysia today needs to exercise more effort and work harder in order to celebrate the solidarity of the Khalsa as their identity and as to prepare the younger generation to undergo amrit sanskar seas one of the vital demands of the Sikh religion. However, their struggle is still on an unpredictable path, at least as long as the challenges are not dealt with as properly as they should be.

\section{Reference}

Agus Salim (1985) Perbandingan Agama, Bandung: C.V. Diponegoro.

Aman Daima Md. Zain ( 2001) Lambang-lambang Agama Sikh di Kelantan : Suatu Kajian Kritis Menurut Ajaran Islam. Masters Thesis, Islamic Study Academy, UM

Archer (1971) The Sikhs, New York: Russel and Russel.

Azharudin Mohd Dali ( 2002) Gerakan Politik di Tanah Melayu Pada Era Perang Dunia I Dengan Tumpuan Kepada Masyarakat Sikh. Seminar The Sikh community di Malaysia, ATMA, UKM, 21 January. pg. 1.

Charanjit Kaur (2002) Sikh Rehat Maryada: Satu Kajian Mengenai Kod Tingkah Laku Penganut Agama Sikh. Latihan Ilmiah. National University of Malaysia.

Darshan S. Gill (2009) Sikh Community in Malaysia. Petaling Jaya: MPH Group Publishing Sdn. Bhd.

Fair, C. Christine ( 2010) The Novel of Bhai Vir Singh and Imagination of Sikh Identity, Community and Nation, Dlm Jakobsh, Doris R. (ed), Sikhism and Women, hlm 115-133, New Delhi : Oxford University Press.

Ganga S. Gyani (1962) Lives of Sikh Gurus and Basic Principles of Sikhism, Budhwar : M.B. Joshi, Dnyanavilas Press,.

H.S. Singha \& Satwant Kaur (1994) Sikhism : A Complete Introduction, New Delhi : Hemkunt Press.

Khoo Kay Kim (2002) Kaum Sikh di Malaysia Dari Perspektif Sejarah. Seminar The Sikh community di Malaysia, ATMA, UKM, 21 January . pg. $10 \& 12$

Khushwant S (1963) A History of the Sikh, Vol. 1, New Delhi : Oxford University Press.

Sahib Singh (1967) Guru Gobind Singh, Delhi : Raj Publishers (Regd), Adda Hoshiarpur, Jullundur City.

Sardar S. Rataul (1964) The Khalsa. Amritsar : The Shiromani Gurdwara Parbandhak Committee.

Sarjit S. Gill \& Charanjit Kaur (2008) Gurdwara and Its Politics : Current Debate on Sikh Identity in Malaysia. Sari, Bangi : Publisher UKM 26:243-255.

Sarjit Singh all Darshan Singh (2005) Peranan Gurdwara Dalam Pembentukan Identity Sikh di Malaysia : Satu Kajian Perbandingan. Ph.D Thesis, UKM

Sarjit S. Gill (2008) Peranan Gurdwara dalam Pembentukan Identity Sikh di Malaysia: Antara Ideal dan Praktis. Akademika, Bangi : Publisher UKM 73:27-50.

Sarjit S. Gill (2001) Perkahwinan Campur Peranakan Punjabi di Sabah. Sari, Bangi : Publisher UKM 19:189-203.

Savinder Kaur Gill \& Nirmala Devi Gopal (2010) Understanding Indian Religious Practice in Malaysia. Journal of Social Science. Delhi: Kamla Raj Enterprises 25(1-2-3): 135-146.

Sikh Naujawan Sabha (1969) Ugama Sikh, Negeri Sembilan : Chang Litho Press. 